\title{
MECHANICAL CHARACTERISTICS OF 9\% Ni STEEL WELDED JOINT FOR LNG STORAGE TANK AT CRYOGENIC
}

\author{
YONG-KEUN YOON, JAE-HOON KIM*, KYU-TAEK SHIM \\ Department of Mechanical Design Engineering, Chungnam National University, 99 Daehak-ro \\ Yuseong-gu, Daejeon, 305-764, Korea \\ * Corresponding author : E-mail :Kimjhoon@cnu.ac.kr
}

YOUNG-KYUN KIM

Korea Gas Corporation, R\&D Division, 973, Dongchun-Dong, Yeonsu-Gu, Incheon-City, 406-130, Korea

\begin{abstract}
To confirm the safety performance of LNG storage tank, the change in fatigue crack growth rate and fracture toughness within X-grooved weld heat-affected zone (HAZ) of newly developed 9\% Ni steel, which was SMAW welded, was investigated. These materials were produced by QT (quenching, tempering) heat treatment. The weld metal specimens were prepared by taking the same weld procedure applied in actual inner shell of LNG storage tank. All tests were performed in the temperature ranging from R.T. and $-162^{\circ} \mathrm{C}$. The fatigue crack growth behavior was carried out using CT specimen. Investigation has been carried out to study the influence of temperature and weld effect on fatigue crack growth behavior. Also, Fracture surfaces after tests were observe by scanning electron microscope (SEM).
\end{abstract}

Keywords: LNG storage tank; 9\% Ni steel; Fatigue crack growth rate; Heat affected zone (HAZ); Cryogenic

\section{Introduction}

The importance of liquefied natural gas (LNG) as a clean energy source has increased more and more under the circumstances of growing economy and increasing demand for energy, while, at the same time, the environmental problems have become major issues among the nations. Natural gas is stored in the tank in the form of LNG, which is liquefied under conditions of atmosphere pressure and the temperature of $-162^{\circ} \mathrm{C}$. Therefore, the inner wall of LNG storage tank directly contacted with LNG must be constructed with a material which possesses high strength and suitable fracture strength at low temperature. LNG storage tank is produced by welded structures. Weld defects which is caused to pores, undercuts and discontinuous joints significantly reduced the fatigue strength of structures. $9 \% \mathrm{Ni}$ steel is widely used around the world as inner wall of LNG storage tank due to its excellent fracture toughness at cryogenic condition. 
This study introduces the result of fatigue crack growth rate of newly developed $35 \mathrm{~mm}$ thick $9 \% \mathrm{Ni}$ steel plate, which is applicable to a $200,000 \mathrm{~m}^{3} \mathrm{LNG}$ storage tank. The purpose of this study is to report on some observations on the effects of changes in load ratio and test temperatures on the fatigue crack growth behavior of base metal and SMAW-welded QT 9\% Ni steel. All tests were performed at R.T. and $-162^{\circ} \mathrm{C}$. The fatigue crack growth behavior was carried out using CT specimen. Also, fracture surfaces after tests were observed by using scanning electron microscope (SEM). Experimental procedures

\section{Experimental procedures}

\subsection{Material}

The material used in this investigation is $35 \mathrm{~mm}$ thick. $9 \%$ Ni plates produced by QT (quenching, tempering) heat treatment. Chemical composition and mechanical properties are shown in Table 1,2 . The tensile and yield strength was more increased at $-162^{\circ} \mathrm{C}$ than that at R.T..

LNG storage tank which is welded by SMAW and SAW is performed horizontal and vertical method. The weld metal specimens were fabricated by taking manual SMAW (shielded metal arc welding) method with welding consumables of $70 \% \mathrm{Ni}$ based Inconel type super-alloys (YAWATA WELD B (M)).

It is well known that weld process can seriously alter the metallurgical and mechanical properties of material, and generally cause degradations of the properties. Therefore, the variation of the cryogenic fracture properties within HAZ (heat affected zone) of weld part must be properly evaluated for the safety performance of LNG storage tanks. Specimens which had been used for compact tension (CT) test were following specifications of ASTM E $647^{[1]}$.

\subsection{Experimental methods}

Hardness for weld point and weld HAZ of $9 \%$ Ni steel used in this study was measured using Micro Vickers-Hardness tester. Measured parts were divided into three sections across the weld HAZ. All fatigue testing was conducted at a cyclic frequency of $6 \mathrm{~Hz}$ on a MTS 810 servo-hydraulic testing machine by using a sinusoidal waveform. Load ratios (R) of 0.1 and 0.5 were applied and held constant for each individual test on separate specimens.

Table 1 Chemical compositions of 9 $\%$ Ni steel (wt\%)

\begin{tabular}{c|c|c|c|c|c|c|c}
\hline \hline Material & $\mathrm{C}$ & $\mathrm{Mn}$ & $\mathrm{P}$ & $\mathrm{S}$ & $\mathrm{Si}$ & $\mathrm{Ni}$ & $\mathrm{Fe}$ \\
\hline $9 \% \mathrm{Ni}$ & 0.05 & 0.67 & 0.004 & 0.003 & 0.25 & 9.02 & Bal. \\
\hline
\end{tabular}

Table 2 Mechanical property of $9 \% \mathrm{Ni}$ steel

\begin{tabular}{r|c|c|c}
\hline \hline Temp. & $\sigma_{\mathrm{y}}(\mathrm{MPa})$ & $\sigma_{\mathrm{u}}(\mathrm{MPa})$ & El. $(\%)$ \\
\hline $24^{\circ} \mathrm{C}$ & 651.6 & 701.1 & 26.6 \\
\hline$-162^{\circ} \mathrm{C}$ & 861.3 & 922.6 & 27.8 \\
\hline
\end{tabular}




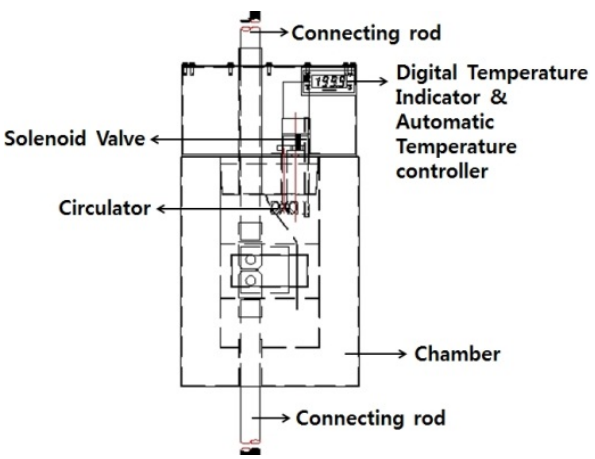

Fig. 1 Schematic diagram of the low temperature experimental apparatus

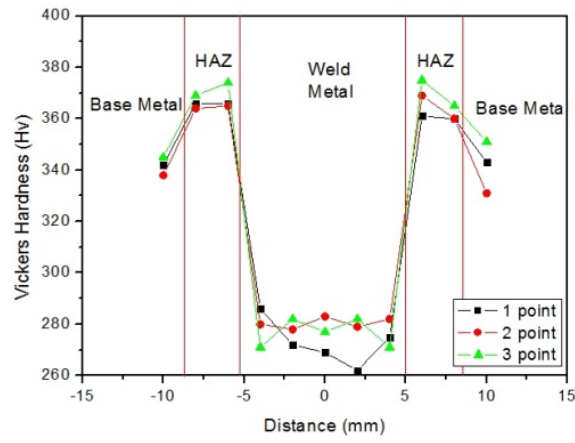

Fig. 2 Micro-vickers hardness for weld metal

Crack growth length was observed using a traveling microscope.

The low temperature in the chamber was maintained to the temperature range of $\pm 3^{\circ} \mathrm{C}$ by controlling solenoid valve using liquid nitrogen. A schematic of the low temperature chamber is shown in Fig. 1.

\section{Results and Discussions}

\subsection{Characteristic of hardness for weld $H A Z$}

Hardness for weld metal of $9 \% \mathrm{Ni}$ steel is shown in Fig. 2. HAZ is higher hardness than base and weld metal. Hardness of HAZ increases due to the grain structure transformation by the welding heat impact. From these results, hardness of HAZ was calculated $\mathrm{Hv}=362$ and hardness of base metal was calculated $\mathrm{Hv}=343$. On the other hand, weld metal is a lower hardness more than base metal and HAZ.

\subsection{The effect of load ratio on fatigue crack growth rates}

The effects of changes in load ratio on the fatigue crack growth rates for $9 \% \mathrm{Ni}$ base metal and weld metal have been investigated. Results of fatigue crack growth experiments which were performed at load ratio of 0.1 and 0.5 at R.T. and $-162^{\circ} \mathrm{C}$ are shown in Fig. 3 and 4. The fatigue crack growth rates of weld metal were nearly the same as those of the base metal irrespective of load ratios changes at R.T.. In the case of $-162^{\circ} \mathrm{C}$, fatigue crack growth rate tends to increase as the load ratio increases, when compared at the same stress intensity factor range $(\Delta K)$.

From these results, residual stress induced by welding in $9 \% \mathrm{Ni}$ steel would have more effects on fatigue crack growth rate under conditions of $-162^{\circ} \mathrm{C}$ than R.T.. In general, fatigue crack growth behavior of absence that have crack is expressed to correlation Eq. (1) of stress intensity factor, is fatigue crack growth rate $(\mathrm{da} / \mathrm{dN})$ and linear elastic fracture mechanic parameter.. Paris suggested the relation of fatigue crack growth rate and stress intensity factor range such as Eq. (1). 


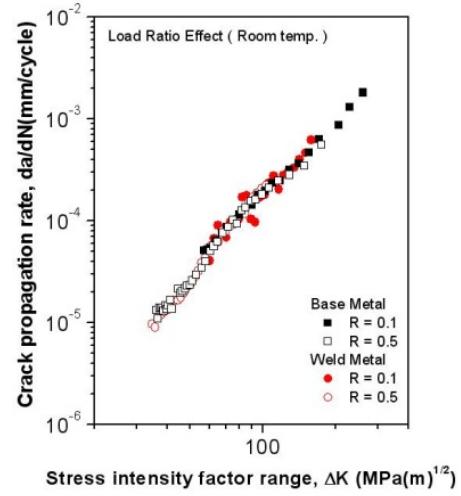

Fig. $3 \mathrm{da} / \mathrm{dN}-\Delta \mathrm{K}$ curves at R.T.

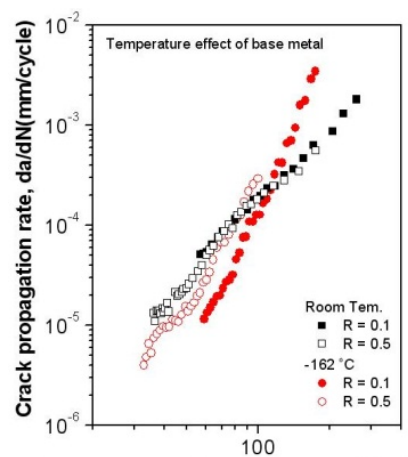

Stress inten sity factor range, $\Delta \mathrm{K}\left(\mathrm{MPa}(\mathrm{m})^{1 / 2}\right)$

Fig. $5 \mathrm{da} / \mathrm{dN}-\Delta \mathrm{K}$ curves for base metal

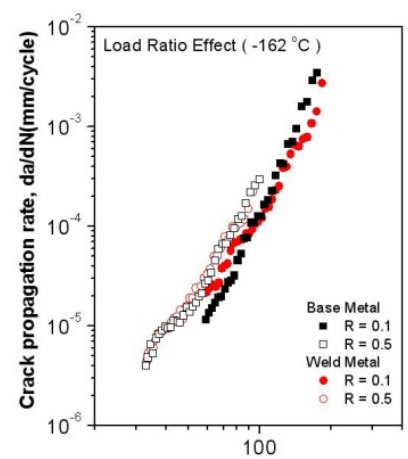

Stress intensity factor range, $\Delta \mathrm{K}\left(\mathrm{MPa}(\mathrm{m})^{1 / 2}\right)$

Fig. $4 \mathrm{da} / \mathrm{dN}-\Delta \mathrm{K}$ curves at $-162^{\circ} \mathrm{C}$

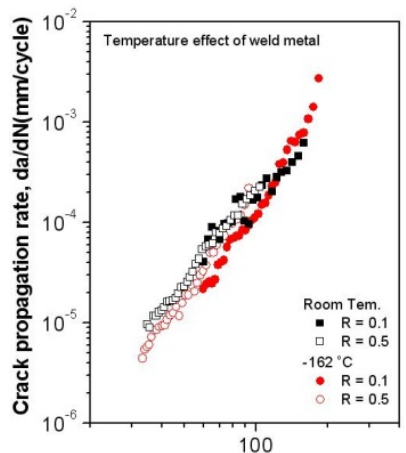

Stress intensity factor range, $\Delta \mathrm{K}\left(\mathrm{MPa}(\mathrm{m})^{1 / 2}\right)$

Fig. $6 \mathrm{da} / \mathrm{dN}-\Delta \mathrm{K}$ curves for weld metal

Table 3 Material constants of $\mathrm{C}$ and $\mathrm{m}$ for $9 \% \mathrm{Ni}$ steels

\begin{tabular}{c|c|c|c|c|c|c|c}
\hline \hline Temp. & $\mathbf{R}$ & $\boldsymbol{C}$ & $\boldsymbol{m}$ & Temp. & $\mathbf{R}$ & $\boldsymbol{C}$ & $\boldsymbol{m}$ \\
\hline \multirow{2}{*}{$\begin{array}{c}\text { R.T. } \\
\text { (Base metal) }\end{array}$} & $\mathrm{R}=0.1$ & $4.829 \times 10^{-9}$ & 2.29 & \multirow{2}{*}{$-162^{\circ} \mathrm{C}$} & $\mathrm{R}=0.1$ & $4.122 \times 10^{-15}$ & 5.28 \\
\cline { 2 - 4 } \cline { 6 - 9 } & $\mathrm{R}=0.5$ & $9.273 \times 10^{-10}$ & 2.63 & & $\mathrm{R}=0.5$ & $1.032 \times 10^{-11}$ & 3.68 \\
\hline \hline $\begin{array}{c}\text { R.T. } \\
\text { (Welded metal) }\end{array}$ & $\mathrm{R}=0.1$ & $4.876 \times 10^{-9}$ & 2.29 & \multirow{2}{*}{$-162^{\circ} \mathrm{C}$} & $\mathrm{R}=0.1$ & $1.765 \times 10^{-12}$ & 3.95 \\
\cline { 2 - 4 } \cline { 6 - 8 } & $\mathrm{R}=0.5$ & $1.593 \times 10^{-10}$ & 3.07 & & $\mathrm{R}=0.5$ & $2.290 \times 10^{-11}$ & 3.49 \\
\hline
\end{tabular}

$$
\mathrm{da} / \mathrm{dN}=\mathrm{c}(\Delta \mathrm{K})^{\mathrm{m}}
$$

Where, $\mathrm{c}$ and $\mathrm{m}$ is material constants

From this relationship, the $\mathrm{c}$ and $\mathrm{m}$ obtained from the relationship were summarized in Table 3. Fig. 7 shows correlation of $\mathrm{c}$ and $\mathrm{m}$ for each load ratio. And correlation between $\mathrm{c}$ and $\mathrm{m}$ for base and weld metal is similar to existing research tendency. 


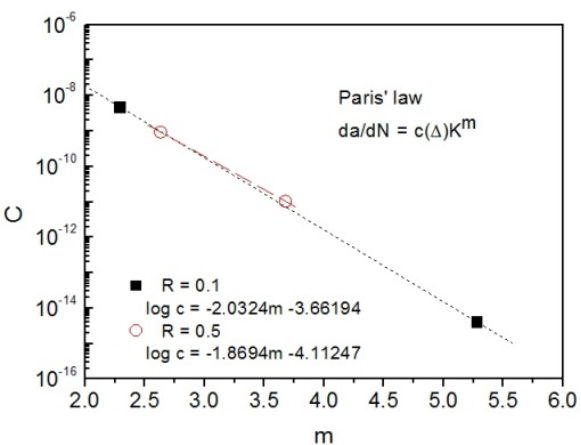

(a) Base metal

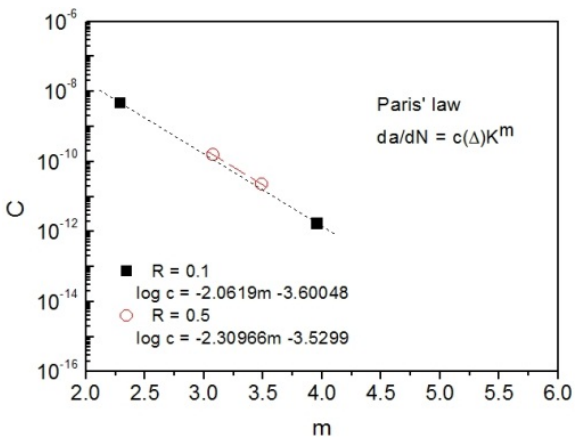

(b) Weld metal

Fig. 7 Correlation between $\mathrm{c}$ and $\mathrm{m}$ for base metal and weld metal

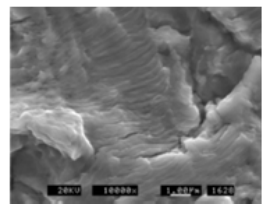

Base metal $(\mathrm{R}=0.1)$

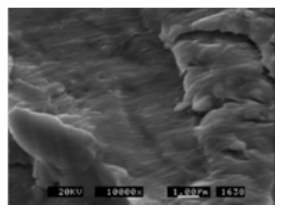

Weld metal $(\mathrm{R}=0.1)$

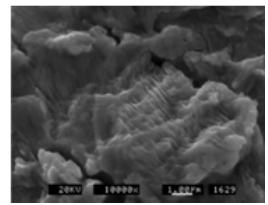

Base metal $(\mathrm{R}=0.5)$

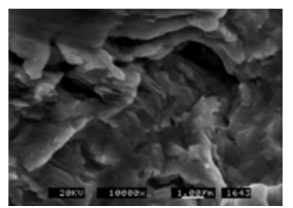

Weld metal $(\mathrm{R}=0.5)$

Fig. 8 Fatigue fracture surfaces of base and welded metals (R.T.)

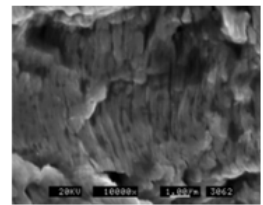

Base metal $(\mathrm{R}=0.1)$

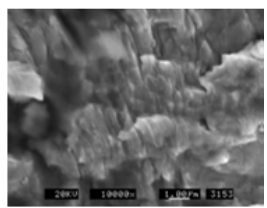

Weld metal $(\mathrm{R}=0.1)$

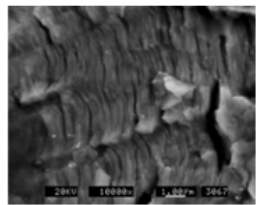

Base metal $(\mathrm{R}=0.5)$

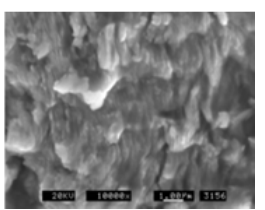

Weld metal $(\mathrm{R}=0.5)$

Fig. 9 Fatigue fracture surfaces of base and welded metals $\left(-162^{\circ} \mathrm{C}\right)$

\subsection{The effect of temperature on fatigue crack growth rates}

The effects of temperature on the fatigue crack growth rates for $9 \% \mathrm{Ni}$ base metal and weld metal are shown in Figs. 5 and 6. The fatigue crack growth rates of base and weld metals are small with decreasing of temperature in the region of lower stress intensity factor range. The resistance of fatigue crack growth at low temperatures was higher compared with the results at room temperature, which was attributed to the extent of strain.

The fatigue crack growth rates for base metal at R.T. and $-162^{\circ} \mathrm{C}$ were reversed above the area of $2 \times 10^{-4} \mathrm{~mm} /$ cycle with increasing of $\Delta \mathrm{K}$. In the case of weld metal, fatigue crack growth rate was observed small scatters. The fatigue crack growth rates were dominated by residual stress due to welding processes rather than temperature effects. It may be caused the change of properties, defect and the change of microstructure due to weld. 


\subsection{Fracture surfaces}

Fracture surfaces were prepared for examination by using a scanning electron microscopy (SME). Fracture surfaces of the $9 \% \mathrm{Ni}$ base and weld steels under changing temperature and load ratio are shown in Fig. $8 \sim 9$. The fracture mechanism of fatigue crack growth shows ductile striations. In general, Machine structural steel is refracted fatigue crack growth by coarsening of microstructure. From these results, the fracture surface pattern is roughly and increases resistance for fatigue crack growth.

Therefore, the degradation of the fatigue crack growth rate according to the degradation of the temperature is regarded strength increase.

\section{Conclusions}

The fatigue crack growth behavior and fracture surfaces of the $9 \% \mathrm{Ni}$ base and weld metal was determined load ratio of 0.1 and 0.5 at R.T. and $-162^{\circ} \mathrm{C}$. Results which obtained from this study were as follows.

1) Hardness of HAZ zone increase due to the grain structure transformation by the welding heat impact.

2) The fatigue crack growth rate of base and weld metals were not affected by the load ratio.

3) The fatigue crack growth rates for base metal at R.T. and $-162^{\circ} \mathrm{C}$ were reversed above the area of $2 \times 10^{-4} \mathrm{~mm} /$ cycle with increasing of $\Delta \mathrm{K}$. And fatigue crack growth rate for weld metal observed small scatters.

4) The fatigue crack growth rates were dominated by residual stress due to welding processes rather than temperature effects.

\section{References}

1. ASTM E647, In Annual Book of ASTM Standards, Vol. 03.01, ASTM-American Society for Testing and Materials, West Conshohocken, PA, 591-630 (1999)

2. ASTM A553, Annual Book of ASTM-Standards Section 1, Iron and Steel Products, 2005

3. J.K.Kim, C.S.Kim, D.S.Kim and I.S.Kim, KSOE, Vol.14, No.1, 23-28

4. D.P. Fairchild, ASTM STP 1058, American Society for Testing and Materials, Philadelphia, 117-141 (1990)

5. A. El-Shabasy and J. Lewandowski, Int. Journal of Fatigue. 26, 305-309 (2004)

6. G.T. Gray and A.W.Thomson, Metallugical Transactions, Vol. 14A, (1983)

7. L. Baotong and Z. Xiulin, Material Science and Engineering, A 148 , 179-188 (1991)

8. Y. Kitsunai and E. Yoshihisa, JSME international Journal, Vol.34, No.3 339-346 (1991)

9. J.H. Baek, Y.P. Kim and W.S. Kim, , Int. Journal of Pressure Vessels and Piping, Vol. 78, 351-357(2001)

10. F.C.Breismeister and C.R Sibley, Welding J.46, No.5, 416-422, (1967)

11. Japan Gas Association Committee, (2000)

12. Mukai K, Hoshino K, Fujioka T, Tetsu-to-Hagane 65:1756-65 (1979)

13. J-B. Lee, J-K. Han, J. Korean Weld. Soc. 13 34-41.(1995) 